\title{
Annika Mikkel, Rütmilised lauselõpud 14. sajandi ladinakeelsetes ning itaalia rahvakeelsetes proosateostes
}

(PhD dissertation, 197 pages with Appendix, University of Tartu Press)

\section{Satu Grünthal*}

Annika Mikkel's doctoral thesis, Rütmilised lauselõpud 14. sajandi ladinakeelsetes ning itaalia rahvakeelsetes proosateostes (Rhythmic clausulae in the 14th-century Latin and Italian vernacular prose texts), published and defended in Estonian, discusses prose rhythm in 14th-century Latin and Italian vernacular (lingua volgare) prose, especially in the works of Dante Alighieri (1265-1321). Mikkel uses the comparative-statistical analysis as her research method. As a comparative data to the works of Dante, Mikkel also analyses texts from other authors, stretching back from the 14th to the 16th century, including Giovanni Boccaccio, Franco Sacchetti, Giovanni Villani, Pietro Bembo and Niccolò Machiavelli.

In ancient rhetoric, the term 'prose rhythm' was used to indicate rhythmical units mostly at the end of sentences and clauses, which in classical prose were called clausulae. The rhythm of classical prose was based on the quantity of syllables. Over centuries, the system of clausulae was simplified and word stress became significant in addition to quantity. Prose rhythm in which the quantity as well as word stress were significant was also called cursus mixtus. This, in turn, developed into Medieval Latin prose rhythm, called cursus, which was purely based on word stress. The use of cursus was most popular in Latin prose, but it could also be found in medieval Italian prose. In the late Middle Ages, four different rhythmic patterns had developed and were in use: cursus planus, cursus velox, cursus tardus and cursus trispondaicus.

Mikkel analyses the types and amounts of cursus that occur in Latin and Italian vernacular prose, and she also examines the use of word boundaries both in Latin and vernacular cursus. The size of data she has used is impressive, comprising altogether more than 11,000 clausulae, leaving the reader with no doubts about its sufficiency. The statistical analysis of the data, carried out with

\footnotetext{
* Author's address: Satu Grünthal, University of Helsinki, Siltavuorenpenger 3A - PL 9, 00014, Helsinki, Finland; email: satu.grunthal@helsinki.fi.
} 
excellent precision, is not only the core of the whole thesis but also Mikkel's most important contribution to Latin and Italian studies. Prose rhythm has so far been studied only in the case of Dante's and Boccaccio's Latin texts, while no systematic statistical analysis of them has been conducted in earlier studies. All results of the statistical analysis are presented in tables in the appendix.

Mikkel's doctoral thesis begins with a short introduction, followed by a more detailed presentation of the history and development of the cursus as well as the theoretical background and the methodology of the study. The second chapter focuses on Dante's work, which is the main target of the study, and the following chapters discuss the other authors, Boccaccio, Sacchetti, Villani, Bembo and Machiavelli. Chapter 8 presents the results of the analysis and brings them together in a comparative discussion. Possibilities for later studies are also briefly discussed.

Annika Mikkel's dissertation is positioned in the strong Estonian tradition of rhythmical and metrical studies, where the importance of statistical analysis of metre is also prominent. Her statistical analysis of the data comprises four stages: a) prosodic analysis, b) input of the prosodic analysis results into a database, c) statistical analysis of the data, and d) comparative analysis of the data. She also discusses the problems that arise in Latin and Italian vernacular prosodic analysis.

In addition to the Estonian tradition of rhythmical and metrical studies, Mikkel's thesis follows a specific path among metrical studies in general, namely that of prose rhythm studies. According to Mikkel, prose rhythm can be studied either in a large or in a more narrow perspective. The large definition of prose rhythm means constructing sentences and their parts in a rhythmically harmonic manner, but her own dissertation, which focuses on the rhythm of clausulae at the end of linguistic phrases, makes use of the more narrow definition of the word. She also brings up the question whether the use of cursus can be seen as a conscious choice of the author or a random incident, or due to the phonological nature of the language. Through her statistical analysis, she succeeds in showing certain author- and work-specific differences in the use of cursus. At least to a certain extent, intentional usage of cursus forms can be observed in Dante's texts, especially in certain chapters of different books. The field of prose rhythm studies is challenging, and not inhabited by many. Although Mikkel's work concentrates on a very specific type of prose, it is a welcome contribution to the discussion and development of prose rhythm studies as a whole.

Annika Mikkel's doctoral thesis is an important contribution to the studies of Latin and Italian vernacular prose rhythm, and the originality of the study lies in its focus, material and method. The research hypotheses are presented 
clearly, and the results of the large comparative statistical analysis are discussed in detail. The overall structure of the dissertation suits the aims of the study well, and the work gives well argued answers to the research questions presented at the beginning - partly by raising new interesting questions and possibilities for further study. Mikkel's thesis bibliography comprises research on Estonian and international classical philology and metrical studies until the present day and in five different languages: Italian, English, Estonian, French and German. Unfortunately, such multilingual and cross-cultural competence, which was earlier regarded as a self-evident ability of all new doctors in the humanities, can no longer be taken for granted. 